\title{
Changes in sources of shared variability of body size and shape in Egyptian local and New Zealand White breeds of rabbits during growth
}

\begin{abstract}
Summary
Correlations between body weight and measurements (body length, thigh circumference, shank length and chest width) at 6, 8, 10 and 12 weeks of age in New Zealand White (NZW), Red Baladi (RB), Black Baladi (BB) breeds of rabbits were studied by factor analysis to disclose the main sources of shared variability, to deduce the factors that describe these characteristics and to quantify breed differences in morphometric size and shape variation during growth.

Differences and similarities between NZW and Egyptian rabbit breeds in factors describing variations in size and shape characters are discussed. At marketing age, compared with local breeds (RB and BB), NZW had higher communality (proportion of variance for a variable that is shared in common by other variables) for chest width and lower communality for body weight and other body shape characters. Compared with NZW, Egyptian breeds varied more in size and less in shape characters. Finding indicated that most of the common variability in live performance traits could be accounted for by two factors with the influence of general factor preponderating. Irrespective of breed, the first factor at various ages was interpreted as a general size factor. The second factor varies with breed and stage of development. In NZW, this factor at all ages (6 to 12 weeks) was described as chest width factor. The second factor in RB was designated to chest width (at 6 and 8 weeks) and a shank length at 10 and 12 weeks. In BB, the second factor was designated to chest width (at 6 weeks), a shank length (at 8 and 10 weeks) and to thigh circumference (at 12 weeks). The importance of the general size factor in relation to the second factor (shape) changes with age. The contribution of the general size factor to the total variance decreased with age in both NZW and RB, but it showed irregular pattern in BB. While that of the second factor increased with advancing age from 6 to 12 weeks in RB and from 6 to 10 weeks in NZW.
\end{abstract}

Key Words: factor analysis, rabbits, body weight variations, body morphological variations, independent variation

\section{Zusammenfassung}

Titel der Arbeit: Veränderungen der Beziehungen von Körpergewicht und Körperformmerkmalen bei Kaninchen während des Wachstums, untersucht an Ägyptischen Lokalrassen und Weißen Neuseeländern Es wurden die Beziehungen zwischen Körpergewicht und den Körperformmerkmalen Körperlänge, Brustumfang, Unterschenkellänge und Brustbreite bei Tieren der Rassen Weiße Neuseeländer (NZW), Red Baladi und Black Baladi im Alter von 6, 8, 10 und 12 Wochen untersucht. Die einzelnen Einflussfaktoren sowie Beziehungen von Körpergewicht zu Formmerkmalen wurden mittels Faktorenanalyse geprüft. Das Wirken von Einflussfaktoren sowie Unterschiede zwischen den Rassen werden beschrieben und diskutiert. Sowohl in der Gewichtsentwicklung als auch den Beziehungen zwischen dieser und den Formmerkmalen sowie diesen untereinander unterschieden sich die Weißen Neuseeländer von den Ägyptischen Lokalrassen. Ebenso veränderten sich die Beziehungen zwischen den einzelnen untersuchten Merkmalen in Abhängigkeit vom Alter der Tiere unterschiedlich.

Schlüsselwörter: Faktorenanalyse, Kaninchen, Variation des Körpergewichtes, Variation der Körperformmerkmale, Zufallsvariable 
1. Introduction

Animal growth involves an increase in body weight (mass) and changes in shape (conformation) of the various component parts of the body. These dynamic processes of multidimensional growth are accompanied by concomitant changes in the phenotypic variances and covariances and their components ATCHLEY and RUTLEDGE (1980). BROWN et al. (1973) used principal components analysis to measure the tendency of bulls to retain the same shapes throughout their preyearling development (at 4, 8 and 12 months). They found that the correlation among principal components at different ages imply that selection on a composites characters, such as weight or general size (first principal component) at young ages may yield bulls which differ in shape at older ages.

Information on the covariance structure of body measurements and weight of animals of different breeds of rabbits and ages treated as multivariate (a series of measurements treated as an entity) rather than bivariates is very limited compared with available in other species. SHAHIN and HASSAN (2000) used factor analysis to identify the main sources of shared variability among body shape characters at marketing age. This study was carried out to identify which part of the variance in body weight and measures can be accounted for by common factors and which part by unique factors and to deduce factors that describe live performance traits in local breeds and NZW breed of rabbits at different ages. Also, this study was designed to quantify differences between breeds of rabbits in morphometric size and shape variation during growth and to show if various body parts merely differ in a random independent fashion.

\section{Materials and Methods}

\section{1. $\quad$ Source of data}

Two hundred and thirty seven (115 male, 122 female) New Zealand White, 137 (71, 66) Red Baladi and $60(29,31)$ Black Baladi young growing purebred rabbits were used in this study. These animals were born over a 2 -year period and represented progeny of 9 and 40 NZW sires and dams, 8 and 13 RB sires and dams and 8 and 20 BB sires and dams. The animals were from Experimental Station, Sakha, Kafr ElSheikh, Animal Production Research Institute, Ministry of Agriculture, Egypt.

\subsection{Management of animals}

Kits were weaned at six weeks of age by removing their mothers from rearing cage and then sexed, tattooed and housed in groups of three individuals in commercial rabbit growing cages. The dimensions of each cage was 40 (width) x 45 (depth) x 30 (height) $\mathrm{cm}$. All rabbits received feed and water ad. libitum and the diet containing approximately $16.3 \%$ crude protein, $13.2 \%$ crude fiber, $2.5 \%$ fat and a metabolizable energy of $2600 \mathrm{Kcal} / \mathrm{kg}$ of diet from weaning to 12 weeks. All animals were maintained under similar management conditions.

\subsection{Traits considered}

The body weight in grams and four different morphological dimensions in millimeters were recorded for each animal at weaning (6 weeks) and then at intervals of 2 weeks until marketing at 12 weeks of age. The following live animal measurements were considered: body length, horizontal distance from the front point of the withers to the 
pinbone; thigh circumference, circumference at the knee-cap (patella); shank length 'tarsometatarsus', from the bottom of the foot pad to the hock and chest width 'transverse diameter of thorax', the greatest width of chest just behind the shoulders. Lengths and width are measured with steel calipers and circumference is measured with measuring tape. To ensure accuracy, each measurement was taken twice and the mean was used in subsequent analysis. The same person throughout took all measurements and weightings, thus eliminating error due to personal differences.

The data from males and females are combined since there were no significant differences between the sexes in the above-mentioned traits (untabulated).

\subsection{Statistical analysis}

The data were subject to principal factor analysis procedure (SAS, 1988). The main source of shared variation among the interdependent body measurements (q) was expressed in terms of fewer mutually uncorrelated common factors FI, FII, Fp (where $\mathrm{p}<\mathrm{q}$ ) than the original measurements (COCK, 1966; DARTON, 1980). The first factor contains the greatest portion of the original variation and in morphometric application of factor analysis, it is designated as a general size factor. Subsequent factors are mutually orthogonal to those preceding and to one another and contain less of the variation.

The model used was as follows:

$$
\mathbf{X}=\boldsymbol{\Lambda} \mathbf{F}+\mathbf{U}
$$

Where $\mathrm{X}=a p \times$ 1vector observational variables; $\boldsymbol{\Lambda}=a p \times q$ matrix of factor loading ' factor - variate correlations, the degree of correlation of the variable with factor' (the pattern matrix); $\mathrm{F}=a q \mathrm{x} 1$ vector of factors (non-observable); and $\mathrm{U}=a p \times 1$ vector of specific 'unique' factor.

The total variance of a variable is equal unity and can be written as the sum of common variance 'communalities' and unique variance 'uniqueness'. The communality represents the portion of the variable variance accounted for by all common factors and the uniqueness represents the portion of the variable variance not ascribable to its correlation with other variables.

\section{Results and discussion}

\subsection{Original 'non-independent' variables}

Table 1 presents the means, standard deviations and coefficient of variability for live weights and dimensions at various ages (6 to 12 weeks of age) for various breed groups. Breed of rabbits differences were significant for most traits at all ages. In NZW, the average body weight at 6 and 12 weeks were 760 and $1171 \mathrm{~g}$ respectively, corresponding values reported by MGHENI et al. (1982) were 785 and $1180 \mathrm{~g}$. The relatively low body weight in the present study as compared to respective trait found in temperate regions may have been due to unfavorable environmental factors, such as temperature and food supply.

The average body weight and body length of NZW and RB rabbits at 12 weeks of age were 2.1 and 1.4 times those at 6 weeks of age, while corresponding values in BB rabbits were 2.3 and 1.5 (Table 1 ).

Regardless of breed, the variation in body weight and body length decreased with advancing age (Table 1). Body weight was more variable than any of the body measurements. At all ages considered in this study, variations in body weight and 
measurements in $\mathrm{RB}$ rabbits were higher than corresponding variations in either $\mathrm{BB}$ or NZW rabbits.

Table 1

Means, standard deviations (SD) and coefficient of variation (CV\%) for live body weight and measurements in various rabbit breeds

\begin{tabular}{|c|c|c|c|c|c|c|c|c|c|c|}
\hline & \multicolumn{3}{|c|}{ NEW ZEALAND WHITE } & \multicolumn{3}{|c|}{ RED BALADI } & \multicolumn{3}{|c|}{ BLACK BALADI } & \multirow{2}{*}{$\begin{array}{c}\text { Significance } \\
\text { - of } \\
\text { difference }\end{array}$} \\
\hline & Mean & SD & $\mathrm{CV} \%$ & Mean & SD & $\mathrm{CV} \%$ & Mean & SD & $\mathrm{CV} \%$ & \\
\hline \multicolumn{11}{|l|}{ At 6 weeks } \\
\hline Body weight (g) & 558.5 & 166.7 & 29.8 & 504.3 & 178.4 & 35.4 & 483.1 & 162.5 & 33.6 & $* *$ \\
\hline Body length (mm) & 203.3 & 25.0 & 12.3 & 198.3 & 28.5 & 14.4 & 193.1 & 26.8 & 13.9 & NS \\
\hline Thigh circumference (mm) & 87.9 & 13.0 & 14.8 & 84.1 & 13.0 & 15.5 & 82.6 & 14.1 & 17.1 & $* *$ \\
\hline Shank length (mm) & 81.3 & 9.0 & 11.0 & 80.3 & 9.5 & 11.8 & 77.5 & 10.4 & 13.4 & * \\
\hline Chest width (mm) & I00.1 & 14.3 & 14.3 & 93.9 & 16.1 & 17.1 & 91.9 & 16.7 & 18.2 & $* *$ \\
\hline Number & 237 & & & 137 & & & 60 & & & \\
\hline \multicolumn{11}{|l|}{ At 8 weeks } \\
\hline Body weight & 760.1 & 198.8 & 26.2 & 709.3 & 207.9 & 29.3 & 698.9 & 192.6 & 27.6 & $* *$ \\
\hline Body length & 234.6 & 23.4 & 10.0 & 226.0 & 24.9 & 11.0 & 225.1 & 24.7 & 11.0 & $* *$ \\
\hline Thigh circumference & 95.8 & 12.0 & 12.5 & 90.6 & 13.2 & 14.6 & 94.5 & 13.0 & 13.8 & $* *$ \\
\hline Shank length & 90.9 & 9.1 & 10.0 & 88.8 & 9.7 & 10.0 & 87.3 & 8.4 & 9.6 & $* *$ \\
\hline Chest width & 112.4 & 14.2 & 12.6 & 106.4 & 17.0 & 16.0 & I11.3 & 15.2 & 13.7 & $* *$ \\
\hline Number & 206 & & & 121 & & & 49 & & & \\
\hline \multicolumn{11}{|l|}{ At 10 weeks } \\
\hline Body weight & 961.4 & 212.5 & 22.1 & 869.3 & 251.4 & 28.9 & 875.5 & 231.4 & 26.4 & $* *$ \\
\hline Body length & 257.3 & 23.5 & 9.1 & 251.5 & 28.0 & 11.1 & 245.7 & 27.5 & 11.2 & $* *$ \\
\hline Thigh circumference & 103.7 & 12.4 & 12.0 & 96.9 & 17.6 & 17.6 & 99.0 & 14.4 & 14.5 & $* *$ \\
\hline Shank length & 98.8 & 8.6 & 8.7 & 96.3 & 9.6 & 10.0 & 95.1 & 9.2 & 9.7 & $*$ \\
\hline Chest width & 123.0 & 16.3 & 13.4 & 115.2 & 17.7 & 15.4 & 118.2 & 19.1 & 16.2 & $* *$ \\
\hline Number & 183 & & & 104 & & & 47 & & & \\
\hline \multicolumn{11}{|l|}{ At 12 weeks } \\
\hline Body weight & 1171.3 & 263.4 & 22.5 & 1065.0 & 294.3 & 27.6 & 1118.6 & 235.8 & 21.1 & $* *$ \\
\hline Body length & 279.8 & 24.4 & 8.7 & 273.5 & 28.2 & 10.3 & 280.1 & 27.5 & 9.8 & NS \\
\hline Thigh circumference & 111.6 & 14.4 & 12.9 & 105.6 & 16.8 & 15.9 & 106.9 & 16.7 & 15.6 & $* *$ \\
\hline Shank length & 105.2 & 8.9 & 8.5 & 104.6 & 9.0 & 8.6 & 105.4 & 9.2 & 8.7 & NS \\
\hline Chest width & 134.1 & 16.6 & 12.4 & 127.1 & 19.3 & 15.2 & 130.5 & 18.8 & 14.4 & $* *$ \\
\hline Number & 176 & & & 93 & & & 42 & & & \\
\hline
\end{tabular}

\subsection{Their relationship}

Correlation coefficients among the original intercorrelated live performance traits for the various breeds at weaning ( 6 weeks), 8, 10 and 12 weeks are given in Table 2 . The magnitude of the correlations among the variables was similar for local breeds and standard breed (NZW) at all ages. Body weight was positively correlated with various body dimensions (Table 2). At six weeks, the correlation was lowest with chest width and highest with body length. Irrespective of breed and stage of development, the lowest correlation was found between chest width and shank length. At 12 weeks, thigh circumference accounted for $71,72 \%$ and $79 \%$ of the variability in body weight of $\mathrm{BB}, \mathrm{NZW}$ and RB, respectively. The correlation of body weight with body length and chest width in NZW was 0.811 and 0.752 , respectively; corresponding values reported by AYYAT et al. (1995) were 0.620 and 0.369. LUKEFAHR and OZIMBA (1991) found a correlation of 0.57 between body weight and body length and corresponding value reported by SHEMEIS and ABDALLAH (1998) was 0.35. 
Table 2

Coefficient of correlation between live body weight and body measurements of various breeds of rabbit

\begin{tabular}{|c|c|c|c|c|c|c|c|c|c|c|c|c|}
\hline & \multicolumn{4}{|c|}{ NEW ZEALAND WHITE } & \multicolumn{4}{|c|}{ RED BALADI } & \multicolumn{4}{|c|}{ BLACK BALADI } \\
\hline & $\mathrm{BW}$ & BL & $\mathrm{TC}$ & SL & BW & BL & $\mathrm{TC}$ & SL & $\mathrm{BW}$ & BL & $\mathrm{TC}$ & SL \\
\hline \multicolumn{13}{|l|}{ At 6 weeks } \\
\hline \multicolumn{13}{|l|}{ Body weight (BW) } \\
\hline Body length (BL) & 0.874 & & & & 0.936 & & & & 0.928 & & & \\
\hline Thigh circumference (TC) & 0.876 & 0.804 & & & 0.879 & 0.856 & & & 0.874 & 0.822 & & \\
\hline Shank length (SL) & 0.851 & 0.838 & 0.743 & & 0.899 & 0.892 & 0.829 & & 0.840 & 0.916 & 0.779 & \\
\hline Chest width (CW) & 0.760 & 0.671 & 0.733 & 0.639 & 0.808 & 0.781 & 0.757 & 0.788 & 0.815 & 0.743 & 0.815 & 0.652 \\
\hline \multicolumn{13}{|l|}{ At 8 weeks } \\
\hline \multicolumn{13}{|l|}{ Body weight (BW) } \\
\hline Body length (BL) & 0.879 & & & & 0.919 & & & & 0.896 & & & \\
\hline Thigh circumference (TC) & 0.866 & 0.810 & & & 0.817 & 0.820 & & & 0.899 & 0.793 & & \\
\hline Shank length (SL) & 0.818 & 0.851 & 0.747 & & 0.873 & 0.836 & 0.761 & & 0.822 & 0.833 & 30.735 & \\
\hline Chest width (CW) & 0.711 & 0.650 & 0.662 & 0.542 & 0.836 & 0.765 & 0.783 & 0.705 & 0.841 & 0.836 & 0.824 & 0.683 \\
\hline \multicolumn{13}{|l|}{ At 10 weeks } \\
\hline \multicolumn{13}{|l|}{ Body weight (BW) } \\
\hline Body length (BL) & 0.852 & & & & 0.866 & & & & 0.921 & & & \\
\hline Thigh circumference (TC) & 0.885 & 0.809 & & & 0.846 & 0.830 & & & 0.914 & 0.867 & & \\
\hline Shank length (SL) & 0.747 & 0.781 & 0.733 & & 0.790 & 0.845 & 0.717 & & 0.801 & 0.860 & 0.747 & \\
\hline Chest width (CW) & 0.607 & 0.512 & 0.551 & 0.411 & 0.876 & 0.823 & 0.850 & 0.663 & 0.847 & 0.847 & 0.799 & 0.715 \\
\hline \multicolumn{13}{|l|}{ At 12 weeks } \\
\hline \multicolumn{13}{|l|}{ Body weight (BW) } \\
\hline Body length (BL) & 0.811 & & & & 0.863 & & & & 0.862 & & & \\
\hline Thigh circumference (TC) & 0.846 & 0.692 & & & 0.887 & 0.806 & & & 0.843 & 0.652 & & \\
\hline Shank length (SL) & 0.754 & 0.749 & 0.655 & & 0.724 & 0.771 & 0.641 & & 0.843 & 0.894 & 0.647 & \\
\hline Chest width (CW) & 0.752 & 0.621 & 0.713 & 0.581 & 0.870 & 0.783 & 0.887 & 0.656 & 0.832 & 0.778 & 0.649 & 0.764 \\
\hline
\end{tabular}

\subsection{Varimax rotated 'independent' factors}

3.3.1. Their interpretation

Factors at 6 weeks. The factors obtained for different breeds are presented in Table 3. Two common factors were obtained representing from $90.7 \%$ (for NZW) to $93.6 \%$ (for $\mathrm{BB}$ ) of the variability of the original 5 variables, leaving $6.4 \%$ to $9.3 \%$ to the 5 'special' factors (Table 3). The way in which these factors contributed to the variation and covariation in each body measurements is shown in the above mentioned Table. The first factor $\left(\mathrm{Fl}_{6}\right)$ ('general size') in each breed is characterized by high positive loadings (factor- variate correlations) on all traits other than chest width (Table 3). This factor showed nearly identical coefficients for each of the five body measure and accounted for $82.5 \%, 87.5 \%$ and $85.6 \%$ of the variation in the original variables in NZW, RB and BB, respectively.

The second factor $\left(\mathrm{FII}_{6}\right.$ ) ('chest width') accounted for an additional 8.2, 5.5 and 8.0\% of the total variation in NZW, RB and BB, respectively. Chest width had the highest loading on it. This factor is mutually orthogonal to the first, present patterns of variation in the different parts of the body (shape) independent of general body size (multicollinearity is no longer present). 
Table 3

Explained variation associated with rotated factor analysis along with communalities of each variable. Correlation between factor score coefficients and original variables in various rabbit breeds

\begin{tabular}{|c|c|c|c|c|c|c|c|c|c|}
\hline & \multirow{2}{*}{\multicolumn{3}{|c|}{$\begin{array}{l}\text { NEW ZEALAND WHITE } \\
\overline{\text { Common factors }}\end{array}$}} & \multicolumn{3}{|c|}{ RED BALADI } & \multicolumn{3}{|c|}{ BLACK BALADI } \\
\hline & & & & \multicolumn{2}{|c|}{ Common factors } & \multicolumn{4}{|c|}{ Common factors } \\
\hline & I & II & Commun & lity ${ }^{\dagger}$ & II & Commur & Iality & II & Communality \\
\hline \multicolumn{10}{|l|}{ At 6 weeks } \\
\hline Body weight & 0.795 & 0.546 & 0.929 & 0.849 & 0.475 & 0.946 & 0.719 & 0.644 & 0.932 \\
\hline Body length & 0.866 & 0.388 & 0.901 & 0.864 & 0.432 & 0.932 & 0.850 & 0.484 & 0.958 \\
\hline Thigh circumference & 0.689 & 0.610 & 0.847 & 0.844 & 0.404 & 0.876 & 0.583 & 0.738 & 0.885 \\
\hline Shank length & 0.893 & 0.308 & 0.893 & 0.817 & 0.477 & 0.895 & 0.914 & 0.341 & 0.953 \\
\hline Chest width & 0.351 & 0.917 & 0.963 & 0.459 & 0.887 & 0.998 & 0.342 & 0.915 & 0.953 \\
\hline$\%$ total variance & 82.5 & 8.2 & & 87.5 & 5.5 & & 85.6 & 8.0 & \\
\hline Description & $\begin{array}{c}\text { General } \\
\text { Size }\end{array}$ & $\begin{array}{l}\text { Chest } \\
\text { width }\end{array}$ & & $\begin{array}{c}\text { General } \\
\text { Size }\end{array}$ & $\begin{array}{l}\text { Chest } \\
\text { width }\end{array}$ & & $\begin{array}{r}\text { Genera } \\
\text { Size }\end{array}$ & $\begin{array}{l}\text { al Ches } \\
\text { wid }\end{array}$ & \\
\hline \multicolumn{10}{|l|}{ At 8 weeks } \\
\hline Body weight & 0.811 & 0.507 & 0.915 & 0.761 & 0.599 & 0.938 & 0.746 & 0.615 & 0.935 \\
\hline Body length & 0.688 & 0.392 & 0.903 & 0.789 & 0.534 & 0.908 & 0.653 & 0.689 & 0.901 \\
\hline Thigh circumference & 0.769 & 0.494 & 0.836 & 0.569 & 0.722 & 0.845 & 0.829 & 0.449 & 0.888 \\
\hline Shank length & 0.923 & 0.212 & 0.897 & 0.894 & 0.364 & 0.931 & 0.378 & 0.910 & 0.971 \\
\hline Chest width & 0.322 & 0.933 & 0.975 & 0.386 & 0.892 & 0.945 & 0.888 & 0.357 & 0.916 \\
\hline$\%$ total variance & 80.6 & 9.9 & & 85.0 & 6.3 & & 85.4 & 6.8 & \\
\hline Description & $\begin{array}{c}\text { General } \\
\text { Size }\end{array}$ & $\begin{array}{l}\text { Chest } \\
\text { width }\end{array}$ & & $\begin{array}{c}\text { General } \\
\text { size }\end{array}$ & $\begin{array}{l}\text { Chest } \\
\text { width }\end{array}$ & & $\begin{array}{c}\text { Gener } \\
\text { size }\end{array}$ & al Sha & \\
\hline \multicolumn{10}{|l|}{ At 10 weeks } \\
\hline Body weight & 0.842 & 0.438 & 0.901 & 0.766 & 0.573 & 0.915 & 0.811 & 0.530 & 0.939 \\
\hline Body length & 0.887 & 0.293 & 0.872 & 0.653 & 0.703 & 0.919 & 0.719 & 0.650 & 0.939 \\
\hline Thigh circumference & 0.846 & 0.378 & 0.859 & 0.835 & 0.438 & 0.887 & 0.830 & 0.451 & 0.892 \\
\hline Shank length & 0.901 & 0.123 & 0.828 & 0.365 & 0.917 & 0.974 & 0.416 & 0.901 & 0.984 \\
\hline Chest width & 0.263 & 0.954 & 0.979 & 0.907 & 0.341 & 0.939 & 0.867 & 0.361 & 0.882 \\
\hline$\%$ total variance & 75.9 & 12.9 & & 85.1 & 7.6 & & 86.7 & 6.1 & \\
\hline Description & $\begin{array}{c}\text { General } \\
\text { Size }\end{array}$ & $\begin{array}{l}\text { Chest } \\
\text { width }\end{array}$ & & $\begin{array}{c}\text { General } \\
\text { Size }\end{array}$ & $\begin{array}{l}\text { Shank } \\
\text { length }\end{array}$ & & $\begin{array}{c}\text { General } \\
\text { Size }\end{array}$ & $\begin{array}{c}\text { Shank } \\
\text { length }\end{array}$ & \\
\hline \multicolumn{10}{|l|}{ At 12 weeks } \\
\hline Body weight & 0.658 & 0.685 & 0.902 & 0.844 & 0.468 & 0.931 & 0.711 & 0.666 & 0.948 \\
\hline Body length & 0.823 & 0.418 & 0.853 & 0.689 & 0.633 & 0.875 & 0.890 & 0.353 & 0.918 \\
\hline Thigh circumference & 0.497 & 0.765 & 0.832 & 0.892 & 0.336 & 0.908 & 0.349 & 0.929 & 0.985 \\
\hline Shank length & 0.884 & 0.308 & 0.877 & 0.352 & 0.922 & 0.974 & 0.889 & 0.341 & 0.906 \\
\hline Chest width & 0.282 & 0.899 & 0.889 & 0.869 & 0.356 & 0.883 & 0.786 & 0.429 & 0.803 \\
\hline$\%$ total variance & 77.6 & 9.5 & & 82.9 & 8.6 & & 82.3 & 8.9 & \\
\hline Description & $\begin{array}{c}\text { General } \\
\text { Size }\end{array}$ & $\begin{array}{l}\text { Chest } \\
\text { width }\end{array}$ & & $\begin{array}{l}\text { General } \\
\text { Size }\end{array}$ & $\begin{array}{l}\text { Shank } \\
\text { length }\end{array}$ & & $\begin{array}{c}\text { General } \\
\text { Size }\end{array}$ & $\begin{array}{l}\text { Thigh } \\
\text { circum }\end{array}$ & ference \\
\hline
\end{tabular}

$\dagger$ Communality: proportion of variation accounted for by both factors (FI and FII).

Factors at 8 Weeks. The first factor $\left(\mathrm{FI}_{8}\right)$ was very similar to $\mathrm{FI}_{6}$ and is interpreted similarly as general size factor. This factor accounted for a larger portion of variation in local breeds than it did in NZW breed although the respective coefficients are similar for all breeds.

The second factor $\left(\mathrm{FII}_{8}\right)$ in NZW explained more of the variation than it did in RB and BB $(9.9 \%$ vs. $6.3,6.8 \%)$. This factor had its highest loading for chest width in NZW and $\mathrm{RB}$ while in $\mathrm{BB}$ it had its highest loading for shank length.

Factors at 10 Weeks. The first factor $\left(\mathrm{FI}_{10}\right)$ ('general size') is characterized by high positive loadings (factor- variate correlation) on all traits other than chest width (in NZW) and shank length (in local breeds) (Table 3). This factor accounted for $75.9 \%$ of the NZW variance and $85.1 \%$ and $86.7 \%$ of the RB and $\mathrm{BB}$, respectively. Wright 
(1932) noted that the genetic differences among breeds of rabbits were large in general size, but to a small extent in group and special factors.

The second factor $\left(\mathrm{FII}_{10}\right)$ in the NZW appeared to be associated with chest width and in local breeds, this factor represents shank length and body length. It accounted for an additional $12.9 \%, 7.6 \%$ and $6.1 \%$ of the total variation in NZW, RB and BB, respectively. TANNER and BURT (1954) re-analyzed rabbits' measurements of WRIGHT (1932) by factor analysis to identify factors that control body weight and bone measurements. They found a basic factor (general size) which affect all measurements, factor for head apart from general size and factor limb. The contribution of limb factor to the total variance was $3.6 \%, 18.1 \%$ and $6.7 \%$ for $\mathrm{Fl}$ black-tan Polishx Polish, F1 Polish x Flemish Giant and F2 Polish x Flemish Giant, respectively.

Factors at 12 weeks. The first factor $\left(\mathrm{FI}_{12}\right)$ appeared to be the same in all breeds and was very similar to those found at 6,8 , and 10 weeks and interpreted similarly as general size factor. This factor is characterized by high positive loadings on all body dimensions other than chest width in NZW, shank length in RB and thigh circumference in BB (Table 3). At this stage of development, $43 \%, 51 \%$ and $71 \%$ of the variation in body weight of NZW, BB and $\mathrm{RB}$, respectively is accounted for by the general size factor, but only $8 \%$ in chest width of NZW, $12 \%$ in shank length of RB and $12 \%$ in thigh circumference of BB. This factor accounted for a larger portion of variation in local breeds than in NZW breed ( $82-83 \%$ vs. $78 \%$ ). CARPENTER et al. (1978) used a principal component analysis in examining the covariance structure of 3 body measurements and weight in cows. They reported that the first principle component accounts for the underlying homogeneity of growth patterns of different body weight and measures. That is at a a particular stage of development, animals that are large for one measurement will tend to be large for the other measurements.

The second factor $\left(\mathrm{FII}_{12}\right)$ in NZW accounted for a further $9.5 \%$ of the variation, which was different from those in RB (8.6\%) and BB (8.9\%). In NZW this factor had high loadings for chest width, thigh circumference and body weight, while in RB it had high loadings for shank length, body length and a moderate loading for body weight. In Black Baladi, it had high loadings for thigh circumference and body weight. The high loading of body weight on the first and second factors suggest that body weight should be excluded from studies designed to analyze particular influences on body shape. It is worth mentioning that when body weight was excluded from the analysis, the contribution of shape factor to the total variance increased, while that of the general size factor decreased (SHAHIN and HASSAN, 2000). It is of interest to note that $81 \%$ of the variation in chest width of NZW, $85 \%$ of the variation in shank length of Red Baladi and $86 \%$ of the variation in thigh circumference of Black Baladi is accounted for by the second factor. It is not known whether the difference between local and NZW breeds is related to the way the weight is distributed over the body, to body conformation or to special breed characteristic peculiar to local breeds, or to other factors.

\subsubsection{Shared variability}

Table 3 lists the communalities for various variables. The variance of a variable was partitioned into a common portion 'communalities' which is shared with some or all of the other variables and a portion unique to that particular variable and not shared with any other variable. Results indicated that, at 6 and 8 weeks, irrespective of breeds, 
thigh circumference had the lowest communality with the greatest uniqueness of its own.

About $84-89 \%$ of the variation in thigh circumference was brought about by common factors, whereas $11-16 \%$ of its variation was contributed by the unique factor specific for thigh circumference. SHAHIN et al. (1993) working with Egyptian buffalo bulls found that communalities for skeletal dimensions (height at withers and height at hips) was much higher than for flesh dimensions (rump width and thigh girth).

At 10 weeks, shank length (skeletal dimension) had the lowest communality in NZW, while in RB, thigh circumference (flesh dimension) had the lowest communality and in Black Baladi, chest width had the lowest communality with the greatest uniqueness of their own (Table 3). TANNER and BURT (1954) found that the lowest and highest communalities in mature Ayrshire cows were found in chest of width and chest circumference.

At 12 weeks, in NZW, the lowest communality for live performance traits was found in thigh circumference (0.83) and the highest (0.90) in body weight. Forty-three of the communality of body weight was due to general size factor and $47 \%$ was due to chest width factor. TOUCHBERRY (1951) in a study of milk production and body measurements of Holstein cows, found that the communality for body weight $(0.93)$ was almost entirely (0.69) due to general size factor with little contribution (0.10) from skeletal group factor and (0.14) from flesh group factor. While in Red Baladi the lowest (0.88) and highest (0.97) communality was found in body length and shank length, respectively. TOUCHBERRY (1951) found that $50 \%$ of the communality of body length was due to general size factor and $20 \%$ was due to skeletal size factor; the balance was determined by special factor for this trait. In Black Baladi, chest width had the lowest communality (0.80) and thigh circumference had the highest (0.99) (Table 3). The communality of body weight, body length, thigh circumference and shank length in local breeds (RB and $\mathrm{BB}$ ) was higher than that in New Zealand White breed.

In conclusion, factor analysis technique explores the interdependence in the original five live performance traits by analyzing them simultaneously rather than individually and help to summarize and explain the correlation patterns among these traits more objectively than is possible by conventional correlations. Compared with NZW, Egyptian rabbit breeds varied more in size and less in shape characters. The contribution of the general size factor to the total variance decreased with age in both NZW and RB, but it showed irregular pattern in BB. While that of the second factor increased with advancing age from 6 to 12 weeks in RB and from 6 to 10 weeks in NZW. These results suggest that an increase in the amount of variation associated with shape characters and a decrease in the amount of variation associated with body size with advancing of age.

\section{References}

AYYAT, M.S.; MARAI, I.F.M.; EL-SAYIAD, GH.A.:

A trial to grade New Zealand White rabbits for broiler production at marketing and breeding. World Rabbit Sci., 3 (1995), 75-84

ATCHLEY, W.R.; RUTLEDGE, J.J.:

Genetic components of size and shape. I. Dynamics of components of phenotypic variability and covariability during ontogeny in laboratory rat. Evolution 34 (1980), 1161-1173 
BROWN, J.E.; BROWN, C.J.; BUTTS, W.T.:

Evaluating relationships among immature measures of size, shape and performance of beef bulls. I. Principal components as measures of size and shape in young Hereford and Angus bulls. J. Anim. Sci 36 (1973), 1010-1020

CARPENTER, J.A.; FITZHUGH, H.A.; CARTWRIGHT, T.C.; THOMAS, R.C.:

Principal components for cow size and shape. J. Anim. Sci. 46 (1978), 370-375

COCK, A.G.:

Genetical aspects of metrical growth and form in animals. The Quarterly Review of Biology 41 (1966), 131-190

DARTON, R.A.:

Rotation in factor analysis. The Statistician 29 (1980), 167-194

LUKEFAHR, S.D.; OZIMBA, C.E.:

Prediction of carcass merit from live body measurements in rabbits of four breed types. Livest. Prod. Sci., 29 (1991), 323-334

MGHENI, M.; CHRISTENSEN, K.; KYOMO, M.L.:

Selection experiment on growth and litter size in rabbits. I. Effect of litter size and growth. Tropical Production 7 (1982), 217-225

SAS:

SAS User's Guide. Statistical Analysis System Institute, Inc., Cary, NC, USA. (1988)

SHAHIN, K.A.; HASSAN, N.S.:

Sources of shared variability among body shape characters at marketing age in New Zealand White and Egyptian rabbit breeds. Ann. Zootech. 49 (2000), 435-445

SHAHIN, K.A.; SOLIMAN, A.M.; MOUKHTAR, A.E.:

Sources of shared variability for the Egyptian buffalo body shape (conformation). Livest. Prod. Sci., 36 (1993), 323-334

SHEMEIS, A.R.; ABDALLAH, O.Y.:

Selection indexes for increased marketing body weight and advantageous body composition in New Zealand White rabbits. Arch. Tierz., Dummerstorf 41 (1998), 597-605

TANNER, J.M.; BURT, A.W.A.:

Physique in the infra-human mammalia: A factor analysis of body measurements of dairy cows. J. Genet., 52 (1954), 36-51

TOUCHBERRY, R.W.:

Genetic correlations between five body measurements weight, type and production in the same individual among Holstein cows. J. Dairy Sci., 34 (1951), 242-255

WRIGHT, S.:

General, group and special size factors. Genetics, 17 (1932), 603-619

Received: 2001-04-25

Accepted: 2002-04-18

Authors' addresses

Prof. Dr. KARIMA A. SHAHIN

Department of Animal Production, Faculty of Agriculture,

Ain Shams University,

P.O. Box 68, Hadayek Shoubra,

11241 Cairo,

Egypt

Dr. NAGY S. HASSAN

Animal Production Research Institute,

Ministry of Agriculture,

Cairo, Egypt 